\title{
Virtual Source of Reactive Power in Electricity Supply Systems of Household Consumers
}

\author{
Mykhailo Korchak*, Olha Sivakova, Yevhen Fediv \\ Lviv Polytechnic National University, S. Bandera St., 12, Lviv, 79013, Ukraine
}

Received: February 12, 2019. Revised: April 08, 2019. Accepted: April 18, 2019.

(c) 2019 The Authors. Published by Lviv Polytechnic National University.

\begin{abstract}
It is proposed to include the principle of distributed generation of reactive power in the basic principles of constructing smart microgrids for non-commercial facilities. Individual reactive power compensation devices should be installed for its implementation at the points of final distribution of electricity networks of buildings and structures. As a result, in addition to the effect of reducing the losses of electricity in distribution networks from the flow of reactive component currents, it is possible to create virtual sources of reactive power as an auxiliary resource at the disposal of the distribution system operator for solving the problem of providing a balance of reactive power in normal and post-accidental transient operational modes for reliable and high-quality power supply. The article substantiates the expediency and expected effect of reactive power compensation in the electric grids of civil engineering facilities.
\end{abstract}

Keywords: power supply systems; reactive power; virtual power plant; virtual reactive power plant; reactive power compensation.

\section{Introduction}

The twenty first century is the era of transition to intellectual technology, and, above all, in the field of power engineering. Ukraine joined this process, as noted in the Technical Policy on the Construction and Operation of Distribution Electric Networks, approved as the operational safety standard of the power system functioning [1].

Virtual Power Plant (VPP) is an efficient resource at the disposal of the smart grid operator to solve the problem of ensuring an active power balance in critical system regimes.

An important task of a smart grid (microgrid) operator is to ensure a balance of reactive power and appropriate voltage levels in the grid that meet the requirements of quality, cost efficiency and reliability of electricity supply. In the event of a lack of reactive power in the distribution grids, regimes with a lower voltage level, which degrade the quality of electric energy and reduce the stability of the work of electric motors of technological installations of consumers, are applied. In addition, the flow of reactive component currents leads to additional energy losses in the elements of distribution networks. Reactive Power Compensation (RPC), as a way of solving problems in electric grids of power supply systems for non-commercial facilities, is currently used to a very limited extent, and in the domestic sector is not used at all.

\section{Overview of known solutions}

VPPs are formed on the basis of: distributed (decentralized) electricity sources, mainly renewable energy sources; distributed resources for the accumulation of electricity (electric power storage) and controlled electrical

*Corresponding author. Email address: misha.korkirov@gmail.com

This paper should be cited as: M. Korchak, O. Sivakova, Y. Fediv. Virtual source of reactive power in electricity supply systems of household consumers. Energy Engineering and Control Systems, 2019, Vol. 5, No. 1, pp. 9 - 14. https://doi.org/10.23939/jeecs2019.01.009 
receivers. It is important that the listed resources, as a rule, are involved in the VPP on a contractual basis by the resources of consumers, which in the concept of intellectual networks are classified as active consumers [2].

Recently, there has been a rapid development of the civil engineering sphere and housing construction in particular. The electrical load of civil engineering facilities is increasing. The consumer sphere is saturated with new electric devices, which leads to the growth of the reactive component in the currents of their supply.

The growth of the density of communal-domestic load, the increase in the consumption of reactive electricity by dwellings of increased comfort, etc., cause a new approach to the issue of the expediency of RPC in the distribution grids of civil engineering facilities, and in the residential sector in particular.

In power supply systems for industrial facilities, the principle of distributed generation of reactive power has been realized for a long time, thanks to economic stimulation - a mandatory fee for the mutual flow of reactive power between the networks of the energy supplier and the consumer. The situation with electrical supply of civil engineering facilities is quite different. The existing regulatory framework for them does not oblige and does not stimulate the establishment of RPC devices. According to [5], the population does not pay for the flow of reactive electricity, and other consumers pay if "... the total average monthly consumption of active electricity at all metering points at one site is $5000 \mathrm{kWh}$ or more." As a result, in energy consumption accounting systems, most of such consumers still do not keep track of reactive energy, including the insignificant volumes of distributed consumption compared to industrial facilities, the occasional nature of electricity consumption, a significant number of singlephase electric receivers, relatively the small claimed power of consumers who pay for electricity, the complexity of the phase adjustment of the RPC devices, etc.

\section{Main part}

The main reason for the violation of the stability of the units of electrical load is the disturbance of the balance of reactive power during electromechanical (long) transients, which is accompanied by understated voltage levels in the distribution network. In such modes, in order to ensure the reliability of the electricity supply, additional reactive power resources from the high-speed regulated source of reactive power should be involved.

We propose, similar to VPP, to create virtual reactive power sources (VRPS) to solve the task of ensuring a balance of reactive power in microgrid, for example, during electromechanical transients in post-accident modes to avoid possible avalanche phenomena and to ensure the reliability of electricity supply. As a resource of reactive power in the VRPS it is expedient to engage the power of distributed means of consumer RPC. Such sources are discretely regulated static capacitors or synchronous motors of technological installations, which are usually based on the principle of individual compensation and which are regulated by the load schedule of the given node, that is, on the consumer's demand.

According to the new "Methodology for calculating the payment for the passage of reactive power", approved by the order of the Ministry of Energy and Coal Industry of Ukraine dated February 6, 2018, No. 87, all consumers of electricity are made equal in their obligations for the payment of reactive electricity, and the fee for the flow of reactive energy is obligatory provided that the authorized power is $16 \mathrm{~kW}$ or more and the consumption or generation of reactive power is $1000 \mathrm{kVA} \cdot \mathrm{h}$. and more [6]. In this case, the creation of the VRPS on the basis of resources of industrial consumers or sufficiently powerful civil engineering facilities is not fundamentally problematic, since the consumer is encouraged to install RPC devices with automatic regulation and metering devices for consumed and generated reactive electricity.

We will carry out an approximate estimation of the efficiency of the use of individual RPC in power supply systems for civil engineering facilities whose consumers are not required to pay for reactive electricity according to [4].

The classic effect of the RPCs use is the reduction of power and voltage losses in the power grid, which is especially promising for municipal utilities, due to the large branching and the extent of the low voltage electrical grids in them:

$$
\Delta \mathrm{P}_{\mathrm{PM}}=\sum_{\mathrm{i}=1}^{\mathrm{n}}\left(\frac{\mathrm{P}_{\mathrm{i}}^{2}+\mathrm{Q}_{\mathrm{i}}^{2}}{\mathrm{U}_{\text {nom }}^{2}} \mathrm{R}_{\mathrm{i}}\right),
$$

where $P_{i}, Q_{i}, U_{\text {nom }}, R_{i}$ are respectively the active and reactive power, nominal voltage, and the active resistance of the $\mathrm{i}$-th element of the distribution network; $\mathrm{n}$ - the number of elements of the distribution network. 


$$
\Delta U_{P M}=\sum_{j=1}^{m}\left(\frac{P_{j} \cdot R_{j}+Q_{j} \cdot X_{j}}{U_{n o m}}\right),
$$

where $P_{j}, Q_{j}, U_{n o m}, R_{j}, X_{j}$ are respectively the active and reactive power, nominal voltage, and the active and reactive resistance of the j-th element of the distribution network; $m$ - the number of elements of the distribution network,

Due to the fact that for elements of low-voltage distribution networks $\mathrm{R}>\mathrm{X}$, the main effect from the use of RPC is to reduce the loss of active power from the flow of reactive electricity, which is estimated to be up to $10 \%$ of the total forwarding, which is an incentive for the application of compensation. Installing RPC devices is especially relevant for systems based on the principles of intelligent power supply, such as active distribution networks (microgrid), with the installation of smart meters and their capabilities to monitor consumption, quality of energy, means of consumption management, etc., to which tasks it is easy and inexpensive to add another.

To illustrate the above arguments, calculations of reactive power consumption levels of typical modern civil engineering buildings in large cities was performed according to the current method [7]. Let us consider three types of multi-apartment houses:

1) 9-storey 6-section residential house with gas stoves for 210 apartments (1st type housing in terms of household appliances and Ist level of electrification according to the estimated specific load in accordance with [3]);

2) 16-storey two-section house with electric stoves and 2 elevators per section (2nd type, IIId level of electrification) for 126 apartments;

3) 24 storey two-section high-rise residential house with electric stoves and 2 elevators per section $\left(2^{\text {nd }}\right.$ type and IVth level of electrification) for 112 apartments and a shopping center with a total area of $10,000 \mathrm{~m}^{2}$.

For the residential buildings, the calculated active load:

$$
\mathrm{P}_{\mathrm{p}}=\mathrm{p}_{\text {spec }} \times \mathrm{N}_{\mathrm{app}}+0.9 \times \mathrm{K}_{\mathrm{d}} \times \mathrm{n}_{\mathrm{el}} \times \mathrm{p}_{\mathrm{el}},
$$

where $p_{\text {spec }}$ is specific calculated electrical load; $\mathrm{N}_{\text {app }}$ is the number of apartments; $p_{\mathrm{el}}$ is installed power of the electric motor of the elevator; $\mathrm{n}_{\mathrm{el}}$ is number of elevators; $\mathrm{K}_{\mathrm{d}}$ is coefficient of demand for lift load.

For the office center:

$$
\mathrm{P}_{\mathrm{p}}=\mathrm{M} * \mathrm{p},
$$

where $\mathrm{M}$ is total area of premises; $\mathrm{p}$ is specific power of electrical equipment for $1 \mathrm{~m}^{2}$.

Taking into account these expressions, the value of the total load capacity is calculated, respectively, for a 9storey 6-section residential building with gas stoves for 210 apartments; A 16-storey two-section residential building with electric stoves (with 2 elevators per section) for 126 apartments; 24-storeyed two-section residential dwelling house of high comfort with electric stoves (with 2 elevators per section) for 112 apartments(Eq.1), as well as a large office center with a total area of $10,000 \mathrm{~m}^{2}$ (Eq.2):

$\mathrm{P}_{\max 1}=210 \times 0.86+0.9 \times 0.65 \times 6 \times 7=205.2 \mathrm{~kW}$,

$\mathrm{P}_{\max 2}=126 \times 1.96+0.9 \times 0.65 \times 2 \times(7+9)=267.2 \mathrm{~kW}$,

$\mathrm{P}_{\max 3}=112 \times 2.48+0.9 \times 0.7 \times 2 \times(7+9)=298 \mathrm{~kW}$,

$\mathrm{P}_{\max 4}=10000 \times 0.2=2000 \mathrm{~kW}$.

Estimated reactive load:

$$
\mathrm{Q}_{\mathrm{P}}=\mathrm{P}_{\mathrm{p}} * \operatorname{tg} \varphi_{\text {norm }}
$$

where $\operatorname{tg} \varphi_{\text {norm }}$ is the normative factor of reactive power.

$\mathrm{Q}_{\max 1}=180.6 \times 0.43+28.14 \times 1.17=110.6 \mathrm{kVar}$,

$\mathrm{Q}_{\operatorname{max2}}=247 \times 0.4+18.7 \times 1.17=120.7 \mathrm{kVar}$, 
$\mathrm{Q}_{\max 3}=277.8 \times 0.4+20.2 \times 1.17=137.6 \mathrm{kVar}$,

$\mathrm{Q}_{\max 4}=2000 \times 0.62=1240 \mathrm{kVar}$.

The average reactive power factor for a typical block with these typical buildings is:

$$
\operatorname{tg} \varphi_{\mathrm{c}}=\frac{\mathrm{Q}_{\mathrm{p} \Sigma}}{\mathrm{P}_{\mathrm{p} \Sigma}}=\frac{110.6+120.7+137.6+1240}{205+267+298+2000}=\frac{1608}{2770}=0.58 .
$$

The obtained result is well correlated with the value of the normative power factor used to calculate the charge for reactive electricity, provided that the consumer does not have the appropriate metering devices in accordance with [5] and the method in the wording of 2002, which has expired in view of the adoption in 2018 of the new method [6]. It should be noted that in [6] the value of the corresponding coefficient is set at the $\operatorname{level} \operatorname{tg} \varphi=0.8$, which confirms the tendency to increase the consumption of reactive power in recent years.

Taking $\operatorname{tg} \varphi=0.6$, the power loss in the i-th element of the power supply will be:

$$
\Delta \mathrm{P}_{\mathrm{i}}=\frac{\mathrm{P}_{\mathrm{i}}^{2}+\mathrm{Q}_{\mathrm{i}}^{2}}{\mathrm{U}_{\text {nom }}^{2}} \cdot \mathrm{R}_{\mathrm{i}}=\frac{\mathrm{P}_{\mathrm{i}}^{2}+\left(\operatorname{tg} \varphi_{\mathrm{c}} \cdot \mathrm{P}_{\mathrm{i}}^{2}\right)^{2}}{\mathrm{U}_{\text {nom }}^{2}} \mathrm{R}_{\mathrm{i}}=\frac{1,36 \cdot \mathrm{P}_{\mathrm{i}}^{2}}{\mathrm{U}_{\text {nom }}^{2}} \cdot \mathrm{R}_{\mathrm{i}} .
$$

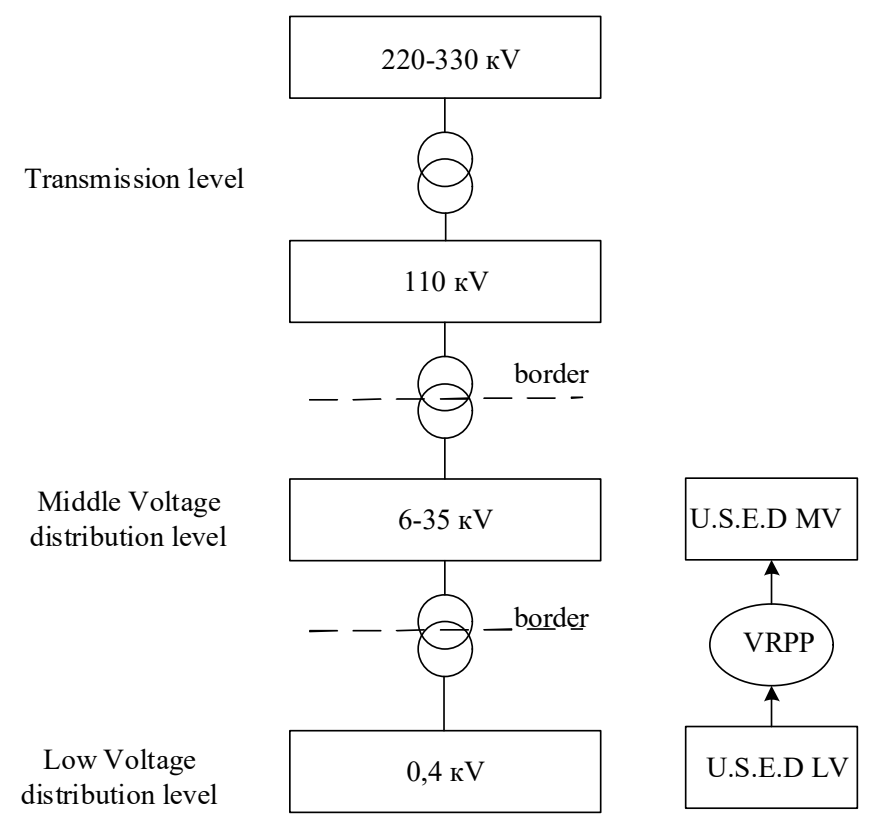

Fig.1. Structural scheme of the energy distribution system.

That is, under full compensation of reactive power at the sections of the distribution network of the household sector facilities, losses from reactive power transfer will decrease by about $30 \%$. For the implementation of full individual compensation for $\operatorname{tg} \varphi=0.6$, taking into account the data in [5], the installed capacity of the devices in the typical residential sector will be from 3 reactive kilovolt-ampere (housing of the 1st type of electrification level I) to 10 reactive kilovolt-ampere (housing of the 2 nd type, Ind level of electrification).

According to the authors' opinion, the effect of the introduction of RPCs in the communal sphere is the receipt of an additional resource of reactive power, which, within the VRPS, formed, for example, by the operator of the low voltage electricity distribution system (low voltage distribution level), may be used, if necessary, by the operator of medium voltage distribution systems (middle voltage distribution level) (Fig. 1). 


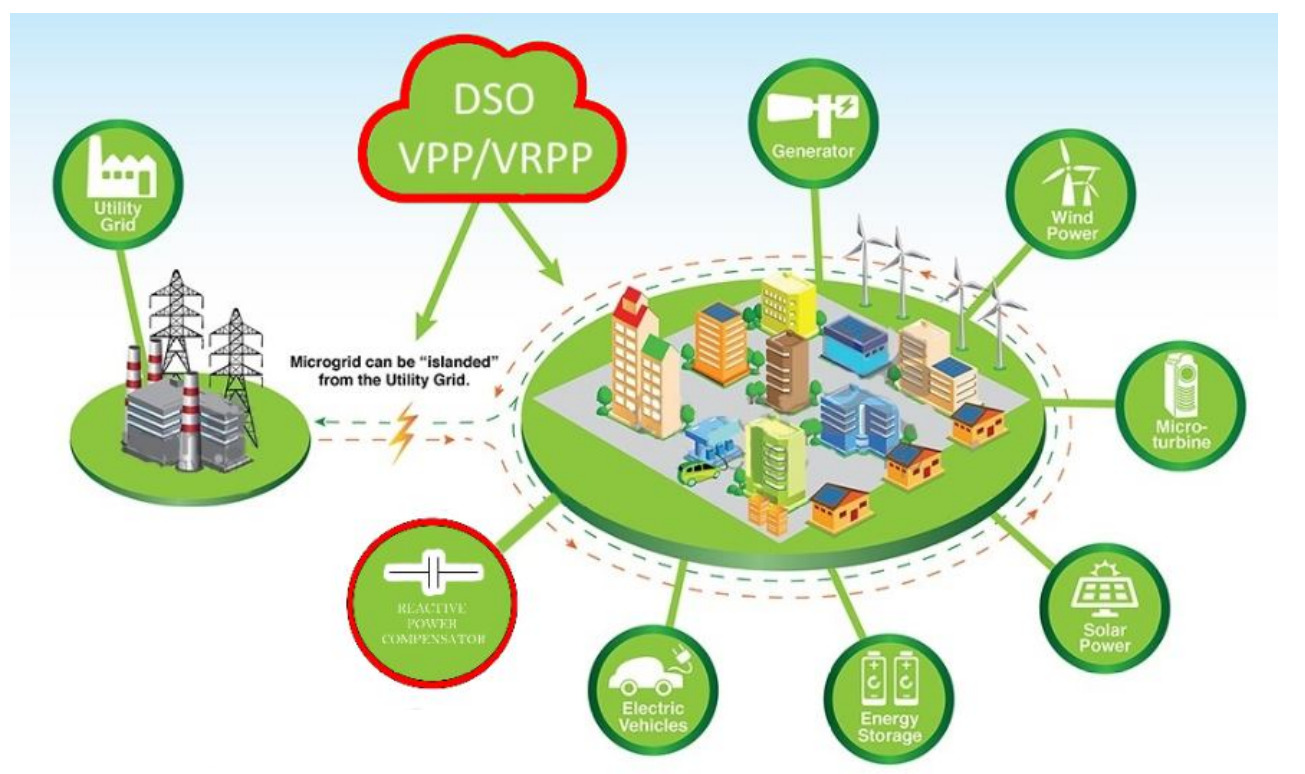

Fig.2. Structure of the future microgrid.

It is known that the main reason for the violation of the stability of the electrical load units is the disturbance of the balance of reactive power during electromechanical (long) transients, which are accompanied by understated voltage levels in the switchgear.

In such modes, in order to ensure the reliability of electricity, it is necessary to involve an additional reactive power resource from a high-speed regulated source of reactive power, which can be used by the VRPS, and resources accumulated in it for a certain time will be removed to maintain the regime of the power grid.

Contribution of the authors to the concept of microgrid facilities of the domestic sector is illustrated by additions to the famous poster [8] highlighted in red (Fig.2).

\section{Conclusion}

In order to more fully implement the concept of microgrid for the supply of electricity for household appliances, we offer:

1. At the regulatory level, stimulate the use of distributed compensation of reactive power with the help of condenser batteries for RPC, which will be managed using IT resources by the electricity distribution system operator.

2. In the receivers and distribution boards of low-voltage distribution systems of domestic electric appliances located at a minimum distance from the places of consumption, provide for a compartment for each consumer, the compartment should contain: condenser batteries, divided into two sections with three levels of regulation on the basis of small-scale cosine capacitors with capacity 1-5 $\mu \mathrm{F}$, microcontroller for selecting the compensation level and contactors that will switch the capacitors.

3. The received resource of the distributed generation of reactive power should be formed as a virtual source of reactive power and provided to the operator of the electric power distribution system to solve problems of ensuring dynamic balance of reactive power, both in the established and transitional operational modes of power supply systems.

\section{References}

[1] SOU MEV EE 40.1-00100227-01: 2016 Standard for operational safety of the functioning of the United Energy System of Ukraine. Construction and operation of electric networks. Technical policy. Part 2. Technical policy in the field of construction and operation of distributive electrical networks. (in Ukrainian)

[2] Intelligent Electric Networks: Elements and Modes. Edited by acad. of National Academy of Sciences of Ukraine O. V. Kyrylenko. Institute of Electrodynamics of the National Academy of Sciences of Ukraine. - K .: Institute of Electrodynamics of NAS of Ukraine, 2016. - 400 p. (in Ukrainian) 
[3] Zorin V.V., Matskevich Yu.M. Compensation of reactive power in risers of high-rise buildings / Power engineering: economy, technologies, ecology, No. 1, 2018. p. 51-58. ISSN 2308-7382 (in Russian)

[4] Lazurenko A. P., Prokhorenko Y. V. Modern methods and devices for compensation of reactive power in household electrical systems. - Kh. NTU "KhPI", 2011. - No. 41, p. 83-87. (in Russian)

[5] DBN V.2.5-23 State building regulations of Ukraine. Engineering equipment of buildings and structures. Designing electrical equipment for civil engineering objects. Kyiv: Ministry of regional development and civil engineering of Ukraine. 2010, 106 p. (in Ukrainian)

[6] Methodology for calculating the payment for the flow of reactive electricity (approved by the order of the Ministry of Energy and Coal Industry of Ukraine, No. 87 of 06.02.2018). (in Ukrainian)

[7] Pavlov V.B., Novsky V.O., Popov V.A., Palachov S.O. Features of the application of charging stations of electric vehicles in urban electric networks. Technical electrodynamics. 2018. No. 6. p. 77-80. https://doi.org/10.15407/techned2018.06.077 (in Ukrainian)

[8] Microgrid Overview: website URL: http://www.greenenergycorp.com/about-us/about-us/technology.

\title{
Віртуальне джерело реактивної потужності в системах електропостачання побутових споживачів
}

\author{
Михайло Корчак, Ольга Сівакова, Свген Федів \\ Національний університет «Львівська політехніка», вул. С. Бандери 12, Львів, 79013, Украӥна
}

\section{Анотація}

Запропоновано включити до складу базових принципів побудови інтелектуальних мікромереж для об'єктів цивільного призначення принцип розподіленої генерації реактивної потужності. Для його реалізації в пунктах прикінцевого розподілу електроенергії мереж будівель і споруд слід встановити індивідуальні пристрої компенсації реактивної потужності. Як результат, окрім ефекту зменшення втрат електроенергії в розподільних електромережах від перетікання реактивних складових струмів, 3'являється можливість створення віртуальних джерел реактивної потужності, як допоміжного ресурсу в розпорядженні оператора системи розподілу електроенергії, для вирішення задачі забезпечення балансу реактивної потужності в нормальних та післяаварійних перехідних експлуатаційних режимах для надійного та якісного електропостачання. Обгрунтовано доцільність та очікуваний ефект від компенсації реактивної потужності в електромережах об’єктів цивільного призначення.

Ключові слова: системи електропостачання; реактивна потужність; віртуальна електрична станція; віртуальна реактивна електрична станція; компенсація реактивної потужності. 